\title{
A theoretical and analytical framework to the inquiry of sustainable land management practices
}

\author{
Ermias Ashagrie \\ Bahir Dar University, Ethiopia
}

\section{Keywords}

Driving forces; Farming system; Land degradation; Livelihoods; Sustainable use of farmlands.

\begin{abstract}
The purpose of this paper is to provide a theoretical and analytical framework by explaining the sustainable livelihoods framework and farming system model from a sustainable point of view. The author studied over 200 publications downloaded using the electronic database search of EBSCO through UNISA online library in June 2018. Keyword combinations of 'land', 'tenure' and 'sustainable use' were used to search for peer-reviewed journal articles published in English from January 1980 to May 2018. The article examines most relevant literature to consolidate the necessary theoretical and analytical foundation in analysing individual and group motivations towards sustainable land management practices. The literature review affirmed that a comprehensive theoretical and analytical framework is scant to empirically analyze the determinants of sustainable land management practices. To partially fill this knowledge gap, the paper provided a generic analytical framework that gives insight not only on pre-decisional processes, but also on postdecisional processes of continued and sustained use of conservation technologies. The analytical framework is developed by combining the sustainable livelihoods framework with the farming system model. It is concluded that the economic theory of property rights may not be adequate as a model to guide land tenure studies and policy. It is recommended that a holistic approach and comprehensive analytical framework is vital for research and development endeavours to ensure sustainable land management practices.
\end{abstract}

\section{Introduction and Motivation}

The purpose of this paper is to provide an analytical framework by explaining the sustainable livelihoods framework and farming system model from a sustainable point of view. This will form the basis to identify the variables and factors that determine sustainable use of farmlands. The majority of empirical literature reviewed focus on the constraints of adoption of conservation measures by farmers; and the conditions that influence sustained use of these measures after adoption are scarcely investigated. But we need to have a better understanding of the conditions that encourage sustained adoption to get an insight on the determinants of sustainable use of farmlands.

From an economic viewpoint, private property rights in land are normally seen as the more efficient institution to ensure sustainable land management practices. This is due to the occurrence of externalities in connection with open access and common property, and to the incentives which they create to sustainable resource extraction (Heltberg, 2002). Despite the absence of a universal land use policy applicable to sustainable agrarian development, there is a global wave towards formalizing rural land holdings (Atwood, 1990; Platteau, 1996; Heltberg, 2002; Fitzpatrick, 2006). These formal mechanisms to enforce individual property rights to farmlands have theoretically attractive tangible benefits to landrelated investment, women empowerment, improved governance, reduced conflict, and lower transaction costs for efficiency-enhancing land transactions (Deininger et al, 2008). As Place (2009) notes a bulk of theoretical and empirical literature amplifies to the encouraging impact of secure property rights in land for sustainable land management practices.

The neoliberal development orthodoxy prescribes a suitable and stable property rights regime for sustainable land management practices, essentially on the grounds of a double-pronged effect. On the one hand, private property rights in land or land titling are considered 'capital' that induces further investment. On the other hand, they have a function in pre-empting potential discord and conflict 
between different tiers of land users/owners by specifying the rights and duties of those in each of the levels. In view of this, a policy discourse of rural land titling programme has been aggressively implemented in various parts of the developing world to redress the problem of farmland degradation. However, the effect of land tenure security, which is expected to accrue from land titling programme, on sustainable land management is a contentious area in the literature. This is mainly because of the inconclusive empirical results that arise from methodological and contextual differences.

Moreover, the interaction between population growth, land degradation and agricultural intensification are most controversial issues of the developing world within the theoretical framework of sustainable development. In the contemporary debates of sustainable land management, the prominent schools of thoughts could be grouped into four theoretical models and arguments. These are the classical school, neo-Malthusian view, Boserup's model and the neoclassical model. Classical economists and neoMalthusians hold a pessimistic view about the effects of population growth on the problems of land degradation. They agree with Malthus's thesis that presupposes population growth with the inevitable result of land degradation. On the other hand, the supporters of Boserup's thesis hold the most optimistic view about the effects of population growth on the problems of land degradation. The Boserup model contends that population growth is a major determinant of technological change in agriculture, leading to innovation, improved land care and thus induced intensification. The neoclassical model supports the thesis of both Malthus and Boserup. The model thus suggests that public policies and development interventions can influence sustainable use of farmlands depending on the dynamics of the local change process and the relative importance of key factors influencing sustainable farming practice.

The neoclassical theory of individualization places great emphasis on market driven property rights structure, and on ensuring the security and efficiency of land transactions but it overlooks important socioeconomic factors that affect how rural productive resources are accessed, used, and contested by individuals or households in support of their livelihoods. In view of this, the paper presents the sustainable livelihoods framework and the farming system model to consolidate the theoretical and analytical foundation to the inquiry of sustainable land management practices.

The author studied over 200 peer reviewed publications using the electronic database search of EBSCO through UNISA online library in June 2018. Keyword combinations of 'land', 'tenure' and 'sustainable use' were used to search for peer-reviewed journal articles published in English from January 1980 to May 2018. Given the limitations to present everything I studied, this article discusses the relevant literature to consolidate the necessary theoretical and analytical foundation in analysing individual and group motivations towards sustainable land management practices.

The paper has five sections, which are organized in the following manner. Section 2 examines the sustainable livelihoods framework that provides the main factors that affect people's livelihoods, and the interrelationships among these factors. Section 3 examines the farming system model that considered the interplay of factors internal and external to a given farming system. Section 4 presents the analytical framework proposed to identify variables and factors that determine sustained adoption of conservation investment for the sustainable use of farmlands. The last section provides a summary of main arguments along with the implications of the article.

\section{The sustainable livelihood framework}

Sustainable livelihoods approaches (SLAs) were developed in the 1980s by various development agencies and organizations and have been adopted, especially since the 1990s, by many as a framework for looking at development issues and addressing poverty (DFID, 2001; Messer \& Townsley, 2003; Thomson, 2000). The Institute of Development Studies (IDS), Sussex, developed the first brand framework of sustainable livelihoods. The sustainable livelihood framework (SLF) provides the main factors that affect people's livelihoods, and the interrelationships among these factors. The framework can be used in planning new development initiatives, for impact assessment of existing activities on livelihood sustainability, and assessing the impact of policies on livelihood strategies and availability and access to assets by households (DFID, 2001; Ellis, 2000; Messer \& Townsley, 2003; Thomson, 2000). 
The SLF was further developed by DFID, building on earlier works of the IDS. According to DFID (2001), it consists of five key components, namely the vulnerability context, the five livelihood assets, transforming structures and processes (now commonly called policies, institutions and processes), livelihood strategies and livelihood outcomes. Diagram 2.1 helps to depict the framework and the relationships between the different elements of the framework.

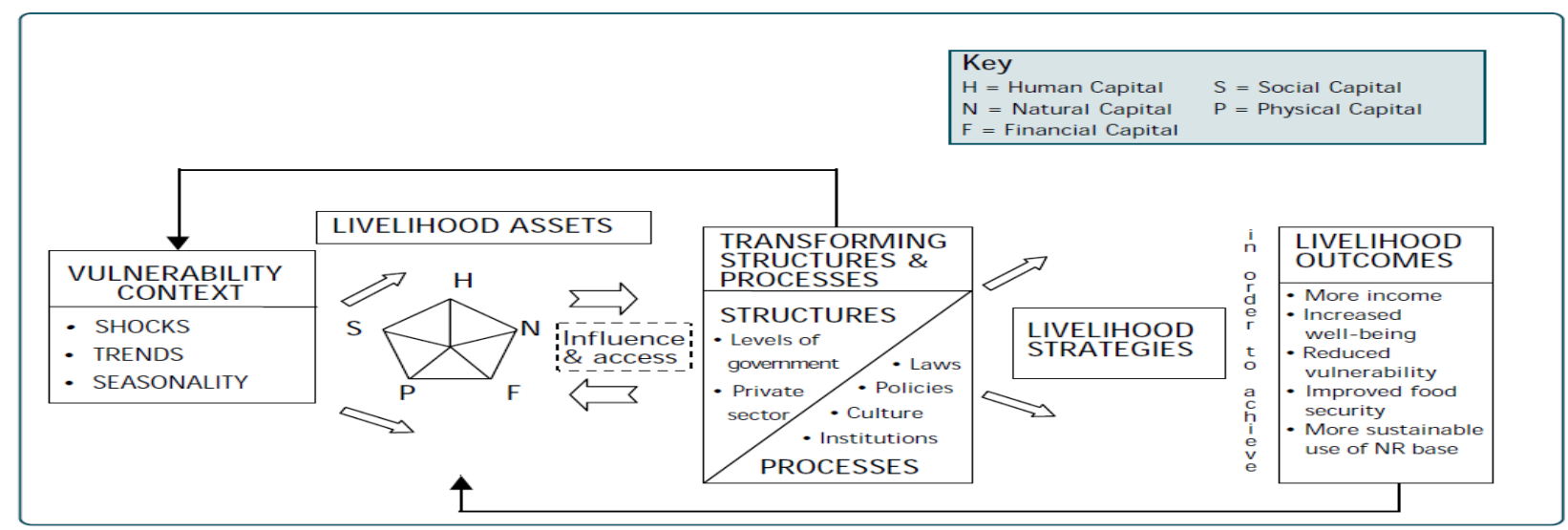

\section{Diagram 2.1 Sustainable livelihood framework \\ Source: Sustainable Livelihoods Framework, Guidance Sheets, DFID 2001}

\subsection{Vulnerability context}

In Diagram 2.1, households are shown to be pursuing their livelihoods in the context of vulnerability. The vulnerability context includes shocks (sudden onset of natural disasters, conflicts, economic traumas, health problems and crop or livestock distress), trends (in population, resources, health problems, the economy or governance) and seasonal constraints (cyclic fluctuations in prices, production, health and employment). This complex of influences has direct and indirect impacts on people's livelihoods, including the options available to them (DFID, 2001). The translation of a set of assets into a livelihood strategy, composed of a range of employment and income earning activities, is normally mediated by the contexts under which people and their portfolio of assets exist (Ellis, 2000). Trends, shocks and seasonality are factors over which people have limited or no control and these might have negative or positive impacts on the availability of assets and thus choice of livelihood activities and strategies (DFID, 2001; Ellis, 2000; Messer \& Townsley, 2003; Thomson, 2000). Policies should be put in place in order to mitigate the negative impacts of the vulnerability context or to take advantage of windfall effects of such unprecedented circumstances (DFID, 2001; Ellis, 2000; Pasteur, 2001; Swift \& Hamilton, 2001; Thomson, 2000).

\subsection{Livelihood assets}

In the SLA, resources are referred to as 'assets' or 'capitals' and are categorised into five asset types owned or accessed by family members: human capital (skills, education, health); physical capital (produced investment goods); financial capital (money, savings, loan access); natural capital (land, water, trees etc); and social capital (networks and associations) (Ellis \& Allison, 2004). Although some asset types may cut across categories, the distinction is useful for analysis. Different assets have varying connections to the policy environment. For example, human capital connects to social policies (education and health), while natural capital connects to land use, agricultural and environmental policies (Ellis \& Allison, 2004).

Ellis (2000) underlines that the assets owned, controlled, claimed or in some other means accessed by the household are the starting points of the SLF. As a people-centred approach, the SLA seeks to gain an accurate and realistic understanding of people's strengths (assets or capital endowments) and how these are converted into positive livelihood outcomes (DFID, 2001; Ellis, 2000). The wider availability of assets determines the range and mix of livelihood strategies to be adapted and adopted over time by a 
household, which results in a positive livelihood outcome (DFID, 2001; Ellis, 2000; Scoones, 1998; Thomson, 2000). The poor have limited access to capital assets, and their livelihood outcomes are more at risk since no single category of assets is sufficient to yield diversified livelihood outcomes. As a result, they have to seek ways of nurturing and combining what assets they have, in innovative ways, to ensure their survival (DFID, 2001).

Some organisations, such as Concern Worldwide (CW), include political capital as a sixth dimension to an asset portfolio (CW, 2006). This is mainly from the understanding that people's participation in policies and the processes largely affects their livelihoods. Thus, policies that help poor people develop and maintain their asset base and diversify their livelihood strategies are essential to sustainable land management practices. To this end, the participation of the poor in the policy-making process largely determines the sustainable positive outcomes of land titling programmes.

\subsection{Transforming structures and processes}

The context of social, economic and policy considerations mediate the translation of assets into a livelihood strategy of income-earning activities (Ellis, 2000). Thus, while stressing the importance of capital assets in people's livelihoods, the SLA recognizes the role of transforming structures (government and private sector) and processes (policies, laws, rules and incentives) on people's livelihoods options. These are important in defining access to assets, and people's livelihood strategies and therefore give meaning and value to livelihood assets (Carney, 1998; DFID, 2001; Scoones, 1998). The term 'transforming structures and processes' (TSPs) has now come to be called 'policies, institutions and processes' (PIPs). According to the DFID framework, TSPs are institutions, organisations, policies and legislation that shape livelihoods, and they operate at different levels (international, national, meso and micro levels), thus determining access to different assets, livelihood strategies, as well as the terms of exchange between different types of capital and returns to any given livelihood strategy (DFID, 2001).

Policies that are decided at the different tiers of the government affect how households make decisions or use available assets. The most common concern around policies and livelihoods is who makes the policies and what are the processes by which they are formed (DFID, 2001; Messer \& Townsley, 2003; Pasteur, 2001; Shankland, 2000; Thomson, 2000). Groups of people who are not consulted about policy or are not represented in the mechanisms that lead to policy formulation have no way of influencing what policies are decided upon. As a result, they may be adversely affected by those policies. Messer and Townsley (2003, p.10) note that 'policies are particularly important for people concerned with improving household livelihoods because policies can be changed'.

Institutions are processes that include a wide range of 'arrangements' found in societies everywhere. These arrangements can be more or less organised (and may include organisations), structured or unstructured, visible or invisible (Messer \& Townsley 2003). Carswell (1997) and Leach et al (1997), in Ellis (2000,p.10) describe institutions as 'regularized patterns of behaviour structured by rules that have widespread use in society'. North (1991) states that institutions are the rules of the game in the society or, more formally, the humanly devised constraints that shape human interaction.

Institutions may thus be formal and informal, often fluid and ambiguous, and usually subject to multiple interpretations by different actors. According to Scoones (1998, p.12), 'power relations' are embedded within institutional forms, making contestation over institutional practices, rules and norms important. Institutions are also dynamic, continually being shaped and reshaped over time. They are thus 'part of a process of social negotiation, rather than fixed objects or bounded social systems' (Scoones, 1998, p.12).

Social relations and institutions determine the way in which structures or organisations and individuals operate and interact. They comprise the agencies that constrain or facilitate the exercise of capabilities and choices by individuals or households, and they furnish the everyday framework, rules and relations for human interaction. Together, structures and processes are important mediating factors of livelihoods because they effectively determine access to public and private resources and terms of trade between types of livelihood assets (DFID, 2001; Ellis, 2000). 


\subsection{Livelihood strategies}

In the past, development efforts were geared towards improving the services and opportunities available to the rural and urban people. With the emergence of SLA, a paradigm shift in thinking about rural and urban development materialized (DFID 2001; Ellis 2000; Messer \& Townsley 2003). DFID (2001) argues that 'the SLA seeks to understand the factors that determined people's choice of a certain livelihood strategy' and 'the livelihoods approach seeks to promote choice, opportunity and diversity' (DFID, 2001,p.28). According to the DFID (2001) framework, the options available to the poor are divided into natural resource based, non-natural resource based, and migration. This expansion of choice and value is important because it provides people with opportunities for self-determination and the flexibility to adapt over time. It is most likely to be achieved by improving poor people's access to assets and to make the structures and processes that 'transform' these into livelihood outcomes more responsive to their needs. This, among others, is promoted through the formulation and implementation of appropriate policies that contribute positively to people's livelihoods (Ellis, 1999; Ellis, 2000). Thus, a basic understanding of existing policies and how they influence people's livelihood strategies becomes imperative.

Livelihood strategies are the ways in which people combine and use assets to meet their objectives. They consist of activities that generate the means of household wellbeing. Ellis has divided livelihood strategies into two categories, natural resource-based activities and non-natural resource-based activities. Natural resource-based activities include harvesting wild resources from forests, cultivation of food or non-food crops, and livestock rearing. They also include non-farm activities like thatching, weaving, or brick making. Some examples of non-natural resource-based activities are rural trading, rural services, remittances and other transfers such as pensions. Livelihood strategies are dynamic, responding to changing challenges that households confront and to which they adapt (Ellis, 2000).

\subsection{Livelihood outcomes}

The dynamic interaction between the elements of the framework ultimately results in activities leading to certain livelihood outcomes in a given period. These are known to change over time because all the elements of the framework are dynamic. Unlike other approaches, the SLA 'seeks to recognize the diversity of livelihood goals which in turn will help to understand people's priorities, why they do what they do and where the major constraints lie' (DFID, 2001, p.31). According to the DFID framework, livelihood outcomes consist of, but are not limited to, more income, increased wellbeing, reduced vulnerability, improved food security and more sustainable use of the natural resource base.

The literature (e.g., Fernandes \& Woodhouse, 2008; Reardon \& Vosti, 1995; Scherr, 2000; Wannasai \& Shrestha, 2007; Vilei, 2011) reveals that poor farmers' income and investment strategies are conditioned by a complex interplay of factors. To begin with, the prevailing driving forces associated with the context of vulnerability, shocks and transforming structures and institutions dictate the type and level of poverty in a certain locality. Second, subsistence agricultural production and resource conservation technologies depend on household assets endowments and require modification of technical rates of substitution among livelihood assets, especially between human-made assets and natural resources. Third, relative input prices, output prices, wages, and the interest rate affect farm resource use and investment incentives. Complementary 'hard infrastructure' (such as culverts, dams, wells, market facilities, and roads) and 'soft infrastructure' (such as extension, schools, and medical services) at village level affect the cost of transactions of inputs and outputs, and thus private costs of investment in resource conservation. Infrastructure also influences the development of non-farm activities, the commercialization of agriculture, and urban-rural links, which are important determinants of income opportunities for the poor. Fourth, community wealth (physical, cultural and social assets) mediates the poor household's options and natural resource conservation behaviour in multiple prongs.

The author shares the widely held view of many scholars (e.g., Besley, 1995; Deininger \& Jin, 2006; Place, 2009; Smith, 2004) on the presence of a knowledge gap in the literature to improve one's understanding of farmers' investment decisions. Earlier studies (e.g., see Amsalu \& de Graff, 2007; Bugri, 2008; Kabubo-Mariara, 2007; Marenya \& Barrett, 2007; Pender \& Gebremedhin, 2007; Shiferaw \& Holden, 1998; Wannasai \& Shrestha, 2007) note that farmers have multiple production objectives and, hence, their risk aversion behaviour may not be easily captured by a universal utility maximization model of 
economic theory. In addition, smallholders' decisions to adopt conservation technologies are mediated by several variables as farm households have a dual characteristic of production and consumption units (Shiferaw \& Holden, 1999). An individual farmer's decision to implement conservation technologies is thus determined by the perpetual influences of the social world that are found in a given farming system (Beshah, 2003; Edwards, 1993; Van de Flier \& Braun, 2002; Vilei, 2011). Edwards (1993, p.104) notes that the movement towards research of a farming system emerged as a response to take into account the complex aspects of various farming systems before designing and introducing any development intervention. In view of this, the farming system model helps to analyse a number of contextual variables such as agro-ecological potential, context specific farming practices, market opportunities, policy implementation discourse, and population density to improve one's understanding of existing empirical results. This highlights the need to regard sustainable use of farmlands from a farming system model within the systems theory perspective, which is often overlooked in conventional development thinking and practice.

\section{Farming system model}

A farming system is conceptualized as a natural resource management model operated by the farm household, along with the engagement of household members in other socioeconomic activities, to ensure their physical survival, as well as their social and economic wellbeing (Vilei, 2011). The model considers the routines of farming practices along with the perpetual influences of the world outside the farm, such as off-farm employment opportunities, migration and education of children (Beshah, 2003; Edwards, 1993; Van de Flier \& Braun, 2002; Vilei, 2011). A given farming system is thus shaped by the interplay of factors internal and external to the system.

Smallholders' adoption and sustained use of conservation technologies, which helps to ensure sustainable use of farmlands, is inherently mediated by several variables in a given farming system. It is more appropriate to treat sustainable land-use practices of smallholders as an outcome of a compromise among multiple variables in a given farming system (Amsalu \& De Graaff, 2007; Bekele \& Drake, 2003). The farming system perspective entered into the arena of systems thinking after the mid-1970s, when researchers began to appreciate the holistic nature of the farming system, which is full of highly interwoven factors (Beshah, 2003; Edwards, 1993; Van de Flier \& Braun, 2002). The farming system perspective presupposes that an individual farmer will make an investment decision by weighing up the relevant elements contained in the farming system, which are characterized by complex relations and interconnections of technical domain, economic domain and the domain of social-organizational relationships (see Beshah, 2003:53; Leeuwis \& Van den Ban, 2004: 62-64). Although the use of variables incorporated in these domains differs among scholars, previous studies have related farmers' decisions on conservation investment to a range of variables that are often classified as personal, physical, socioeconomic and institutional factors (eg see Amsalu \& De Graff, 2007; Bekele \& Drake, 2003; Bugri, 2008; Gebremedhin \& Swinton, 2003; Kabubo-Mariara, 2007; Marenya \& Barrett, 2007; Mekonnen, 2009; Pender \& Gebremedhin, 2007; Pender \& Kerr, 1998; Shiferaw \& Holden, 1998; Wannasai \& Shrestha, 2007).

The farming system model is particularly useful for the inquiry of sustainable land management practices for two reasons. First, it provides concepts and models for describing and analysing endogenous and exogenous variables that affect sustainable land management practices in a given context. Secondly, it provides a broader framework for investigating and analysing the dynamic feedback of social actors because of changes in organizing principles and rules that mediate an individual farmer's perceptions of sustainable land management practices. Diagram 3.2 below shows the selected farming model used for apparent discussion. 


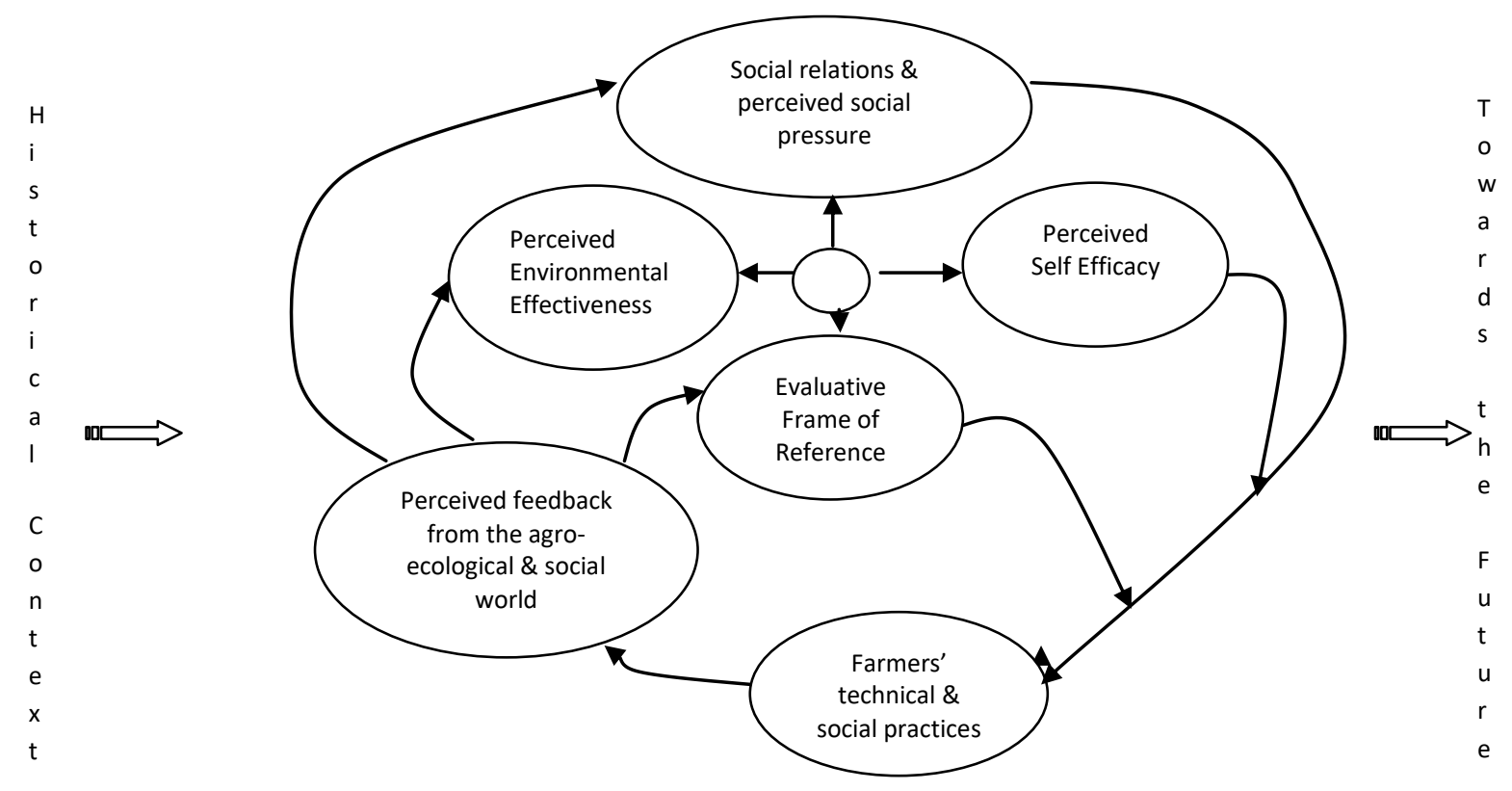

Diagram 3.2 Farming System Model

Source: Leeuwis and Van den Ban 2004:66

Leeuwis and Van den Ban (2004: 66-86) introduced a comprehensive farming system model that helps to visualize important variables that may shape an individual farmer's practices and/or responses towards sustainable use of farmlands. In this model, they contend that evaluative frame of reference, perceived environmental effectiveness, perceived self-efficacy, social relations and perceived social pressure shapes farmers' technical and social practices. This circular model also shows that seasonal farming practices consider the dynamic feedback coming from the practices of social actors. This feedback is always perpetual in nature having a continuous motion that regards the diverse feedbacks coming at different levels and domains of the farming system on the spectrum of time. That is, even if actors are not deliberately seeking feedback, they are always in what is termed as 'reflective monitoring of action' (Giddens, 1984,p.5, in Leeuwis \& Van den Ban, 2004,p.81).

The essence of this comprehensive farming system model, which is represented in Diagram 3.2 above, is that an individual farmer's decision on conservation investment is shaped by not only a single perception of tenure security, but also by a careful balance of numerous considerations and tradeoffs. To begin with, the knowledge and beliefs of farmers can originate from various sources, such as local, external, scientific and mutual knowledge. Their 'evaluative frame of reference' is closely related to their knowledge and mode of reasoning about the natural, economic and social world. This overall inclination towards specific farming practice, which is simply termed as 'attitude' by social psychologists, is a result of multiple variables associated with perceived technical and socioeconomic benefits, risk perceptions, and valuation of risks and consequences. Their perceptions about the likelihood of technical, economic, and socio-organizational risks are valued with respect to a set of aspirations. The major sets of aspirations, which assumes different order of importance across the spectrum of time and space, comprise technical (economic), relational (political), cultural and emotional goals and interests of individual actors (Leeuwis \& Van den Ban, 2004, p.67-71). 
In addition, the notion of 'perceived environmental effectiveness' in the farming system model implies that an individual farmer's decision on conservation investment is shaped by his or her level of trust in the functioning of the social environment. Especially, by his or her perceptions associated with the effectiveness of those existing agro-support networks and intercommunity organizations. An individual farmer's confidence in his or her ability, which is termed as 'perceived self-efficacy' in Diagram 3.2, may also be a hurdle to adoption of beneficial conservation technologies when he/she thinks that he/she cannot properly or realistically apply them (Leeuwis \& Van den Ban, 2004,p.69).

Moreover, the notion of 'social relations and perceived social pressure' in Diagram 3.2 implies that farmers' practices are shaped by both direct and indirect pressures they experience from other actors with whom they relate and/or associate. These actors include spouses, children, relatives, village leaders, donors, government agencies, extension workers, agro-industry, and politicians. The pressure and influence of these actors or agencies largely originates from their evaluative frame of reference that in turn value costs and benefits with respect to their aspirations. The aspirations of these actors range from a strong intension to maintain power relations, a desire to meet national economic needs, or a wish to maintain cultural norms and values (Leeuwis \& Van den Ban, 2004, p.71-79).

Therefore, the essence of the farming systems model is that an individual farmer's 'cognitive system' is made up of a complex and dynamic web of interrelated perceptions. The model has a dynamic nature compared to the economic theory of property rights in explaining an individual farmer's land management practices. It indicates that a large variety of cultural, technical, economic and relational aspirations and preferences has a role in shaping an individual farmer's land management practices. Thus, it presupposes that there are different ways of doing things right in a given farming system in contrast with the economic theory of property rights that sees the individual as the only actor who is potentially capable of undertaking sustainable land management practices over which he had private property rights. The economic theory of property rights fundamentally presupposes that there exists only one rationally optimal way of allocating production means and organizing sustainable land management practices.

The SLF of DFID covers the full diversity and richness of livelihoods and associated dynamic effects of 'driving forces' on the environmental degradation. The framework acknowledges that driving forces to context specific farming practice ('response') are various social, economic and political forces as well as 'natural' factors. In simple terms, it considers 'response' of a given farming behaviour or livelihood strategies as the outcome of not only farmers' (resource users) decisions at the local level but also changes in legislation and policy at the level of the national government. The five categories of livelihood assets (natural, physical, social, financial and human capitals) within the SLF clearly correspond to a particular environmental condition or 'state'. It then suggests that a 'response' to a particular environmental condition or 'state' becomes a 'driving force' that will influence future conditions of environmental state in a circular flow. The indicators of the 'state' or components of livelihood assets thus have an important implication for the outcomes of existing 'driving forces' and also the effectiveness of current 'response' (see Fernandes \& Woodhouse, 2008,p.245-246). Moreover, the livelihood assets, which could be termed as stock of capitals in the economic jargon, cover the important social, economic and ecological aspects of sustainable development emphasized by the Brundtland model.

\section{Analytical framework proposed}

The author combined the sustainable livelihood framework developed by DFID (2001) and the farming system model of Leeuwis and Van den Ban (2004) to present a generic analytical framework for context specific inquiry. The SLF asserts that the prevailing external environment that mediates the status of livelihood assets at household level dictates land users' livelihood strategies, thereby their behaviour towards dynamic farming practices over time (see section 2). The farming system model also articulates that an individual farmer makes a decision on sustainable land management practice by weighing up the complex relations and interconnections of technical domain, economic domain and the domain of socialorganizational relationships (see section 3).

The various socioeconomic, cultural and institutional, as well as biophysical and technical factors that could potentially affect the sustainable use of farmlands, are also discussed and analysed with the aid of 
the analytical framework presented in this section. Diagram 3.3 below shows a basic sketch of the analytical framework suggested by the author.

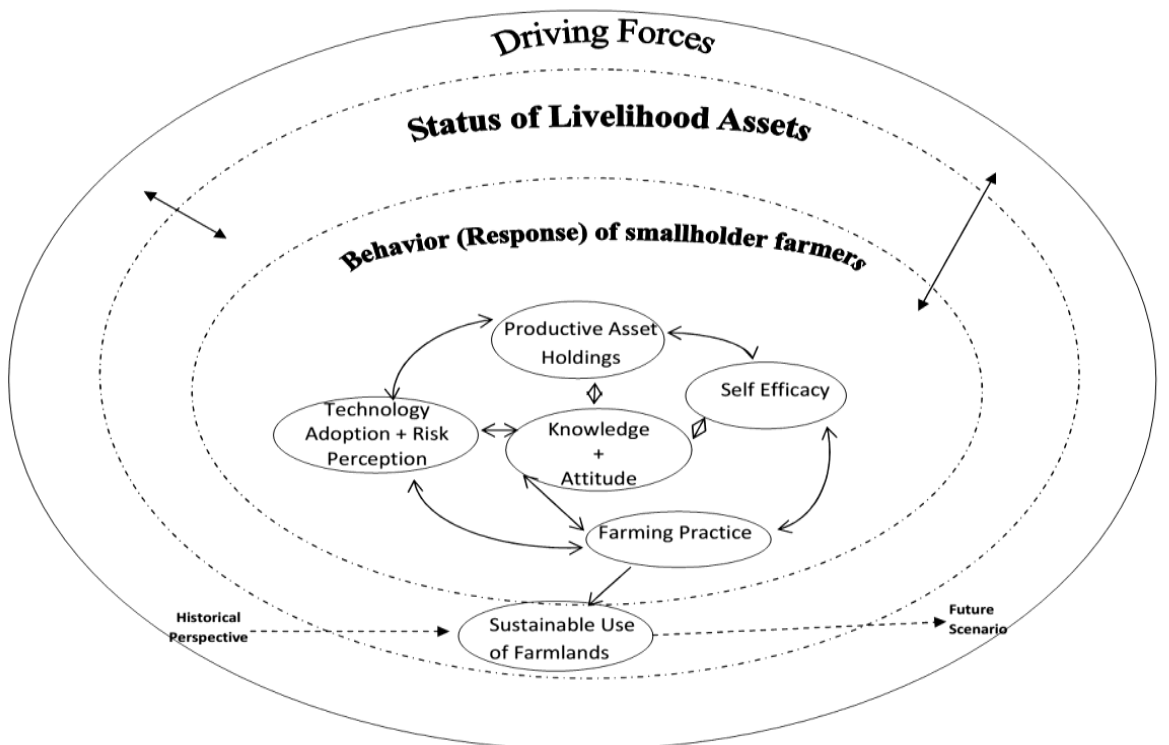

Diagram 3.3 Analytical framework suggested for empirical work

Source: Own hybrid

The analytical framework presented in Diagram 3.3 above, based on the SLF and the farming system model, makes certain assumptions:

The behaviour (response) of smallholders towards a particular farming practice in a given period depends upon their productive asset endowments, self-efficacy, knowledge and attitude, and technology adoption and risk perception (see the inner circle).

These determinants of smallholders' behaviour in turn are mediated by driving forces that allocate productive resources among farm households (see a double-headed arrow that connects the inner circle with the outer circle).

The initial farming practice would become a driving force to the next production period through its effect on the status of livelihood assets available to farm households (see a double-headed arrow that connects the middle circle with the outer circle). That is, the outcome of the current farming practice determines the status of farmland available to farm households, which in turn becomes a driving force to the next production period. If the outcome of current farming practice results in the proper use of farmlands, it would become a positive driving force since it enhances the status of livelihood assets available to the next production period. If the outcome of current farming practice results in degradation of farmlands, it would become an adverse driving force as it depletes the status of livelihood assets available to the next production period. The single-headed arrow that connects 'farming practice' with 'sustainable use of farmlands' shows a cause-effect relationship between farming practice and driving forces. Thus, farmland is assumed to be the most important productive asset possessed by farm households, which dictates the status of other productive asset endowments.

Driving forces considered in the analytical framework comprise three aspects: i) the vulnerability context associated with demography and land degradation; ii) shocks associated with droughts, flood, pest and diseases; and iii) transforming structures and processes found at various spatial levels, such as laws, policies and institutions that allocate means of production and distribution of outputs. The analytical framework also considered five types of livelihood assets or capitals such as natural, physical, social, human and financial capitals discussed in SLF. These five capitals are considered since they 
determine the productive asset endowments, self-efficacy, knowledge and attitude, and technology adoption and risk perception of farm households.

Diagram 3.3 shows that driving forces of the external environment shape livelihood strategies of smallholders, and thereby their behaviour to particular farming practices across space and time. The inner circle of the diagram also shows the synergy of multiple variables that shape the initial farming practices of an individual farmer. The variables included in the inner circle were based on the theoretical propositions discussed in the farming system model. The diagram also illustrated that an individual farmer's farming practice determines the status of renewable natural capital (farmlands) on which his or her livelihood depends. The status of this livelihood asset along with other forms of capital, determines his or her productive asset holdings (see a single-headed arrow that connects farming practice with sustainable use of farmlands included at the middle circle). The middle circle traces the status of current livelihood assets that are expected to have a dynamic synergy with the driving forces (see a doubleheaded arrow that connects the middle and outer circles). The diagram finally shows that the initial farming practice becomes a driving force that shapes an individual farmer's experiential learning or his or her sustainable land management practices. The expected synergies are shown in the analytical framework using double-headed arrows that link status of livelihood assets with driving forces, driving forces with the behaviour (response) of an individual farmer, and among variables assumed to mediate the behaviour (response) of an individual farmer. The analytical framework also uses broken arrows to show the expected linkages between past (historical perspective of) driving forces and the outcome of current farming practice (concept of 'sustainable use of farmlands'), as well as the linkages between anticipated outcome of current farming practice and the future scenario of driving forces.

The analytical framework helps us to understand not only the pre-decisional processes, but also the post-decisional processes of continued and sustained use of conservation technologies. The pre-decisional processes are illustrated by the inner circle, which assumes the determinants of smallholders' behaviour (response) towards a particular farming practice. A single-headed arrow connecting farming practice with sustainable use of farmlands, and a double-headed arrow connecting the middle circle with the outer circle illustrate the post-decisional processes. The analytical framework also tried to connect the microeconomic behaviour of smallholders with the macroeconomic institutional support systems provided to the farming community. This framework considers the various socioeconomic, cultural and institutional factors, as well as biophysical and technical factors that could potentially affect the sustainable use of farmlands in the context of the study area.

\section{Conclusion and Implications}

This paper is an outcome of the observed mixed and inconclusive empirical literature on the role of land tenure security on sustainable land management, observed evidence of multiple variables that mediate farmers' decision on conservation investment, and contemporary debates of sustainable land management. The role of the economic theory of property rights about land tenure reform in sub-Saharan Africa was assessed and its adequacy as a model to guide land tenure studies and policy was found limited.

A major concern of scholars interested in African land tenure and agricultural development has been the lack of empirical evidence in support of the theoretical benefits of land tenure security accrued from a formally registered land title. This concern has given rise to quantitative studies based on survey research and econometric analysis by the grant obtained from the World Bank and the Land Tenure Centre (LTC) in most cases. The main objective of these studies was to analyse the extent to which expected outcomes of perception of land tenure security on farm productivity and land-related investment. Analysis of data was based on a theoretical model relating perception of land tenure security to farm productivity (Feder et al, 1988), and a mathematical model used to analyse the investment-enhancing effects of security of land tenure (Besley, 1995). Nevertheless, the theory of property rights cannot assess the adequacy of land tenure security on sustainable farming practice in African rural situations on economic considerations alone. It emphasizes market-driven property rights, and ensuring the security and efficiency of land transactions, but overlooks important socioeconomic factors that affect how rural productive resources are accessed, used, and contested by individuals or households in support of their livelihoods. 
The context of this article should be seen as the emerging discourse of careful empirical investigation in examining the links between land rights, conservation investment and sustainable land use. In view of this, the author examined relevant literature to consolidate the necessary theoretical and analytical foundation in analysing individual and group motivations towards sustainable land management practices. The author examined the SLF framework provided by DFID (2001). The SLF presented in the article seeks to understand the dynamic relationship among the vulnerability context, livelihood assets, transforming structures and processes, livelihood strategies and livelihood outcomes. It thus sees farmers' motivations towards sustainable land management practices as the outcome not only of farmers' (resource users) decisions at local level, but also dynamic changes in the vulnerability context, status of livelihood assets possessed and changes in legislation and policy at the level of the national government.

In addition, the article examined the farming system model developed by Leeuwis and Van den Ban (2004). This comprehensive farming system model asserts that knowledge and perceptions are not neutral but are subject to social influences and related to social interest. It thus presupposes that the learning process of individual farmers is always changing with the deliberateness and consciousness dynamism of the social environment. In line with this, the article examined the theoretical propositions of indigenous knowledge and social learning to show the silent determinants of farmers' decisions on conservation investment. The dynamism of various variables in a given farming system implies that a rational and optimal decision of last year's conservation investment may not be rational and optimal this year to the same individual, let alone to other individuals.

The major shortcoming of this article is failure to accommodate the diverse brands of farming system models and SLF available in the literature. In addition, the article has considered limited number of peer reviewed literature published only in English language using keyword combinations of 'land', 'tenure' and 'sustainable use'.

The author provided a generic analytical framework that helps to gain insight not only on predecisional processes, but also on post-decisional processes of continued and sustained use of conservation technologies. The analytical framework is developed by combining the SLF with the farming system model. A holistic approach and comprehensive analytical framework are suggested to properly understand the synergy of the variables and factors that affect the sustainable use of farmlands across space and time. It is thus recommended that adopting these methodological and theoretical considerations in both qualitative and quantitative research could help to improve one's understanding of the relationship between security of land tenure and sustainable use of farmlands.

\section{References}

Amsalu, A \& de Graaff, J. (2007). Determinants of adoption and continued use of stone terraces for soil and water conservation in an Ethiopian highland watershed. Ecological Economics 61(2-3):294-302.

Atwood, DA. (1990). Land registration in Africa: the impact on agricultural production. World Development 18(5):659671.

Bekele, W \& Drake, L. (2003). Soil and water conservation decision behavior of subsistence farmers in the Eastern highlands of Ethiopia: a case study of the Hunde-Lafto area. Ecological Economics 46:437-451.

Beshah, T. (2003). Understanding Farmers: Explaining soil and water conservation in Konso, Wolaita and Wello, Ethiopia. Published PhD Thesis, Wageningen University and Research Centre.

Besley, T. (1995). Property rights and investment incentives: theory and evidence from Ghana. Journal of Political Economy 103(5):903-936.

Bugri, JT. (2008). The determinants of tenure security, agricultural production and environmental degradation in Africa: evidence from stakeholders in north-east Ghana. Land Use Policy 25:271-285.

CW(Concern Worldwide).2006. Program Focus, Livelihoods Approach. [O]. Available from:

$<$ http://www.concern.net/overseas/programmefocus/livelihoodsapproach.php> [Accessed on 3 February 2007].

Deininger, K \& Jin, S. (2006). Tenure Security and Land-Related Investment: Evidence from Ethiopia. European Economic Review 50(5):1245-1277.

Deininger, K, Ali, DA \& Alemu, T. (2008). Assessing the functioning of land rental markets in Ethiopia. Economic Development and Cultural Change 57(1):67-100.

DFID. (2001). Sustainable Livelihoods Guidance Sheet. [O]. Available from:

< http://www.livelihoods.org/info/info_guidancesheets.html> [Accessed on 25 January 2007].

Edwards, R.1993. Traditional farming systems and farming systems research, in Dryland Farming in Africa, edited by JRJ Rowland. London and Basingstoke: Macmillan 
Ellis, F \& Allison, E. (2004). Livelihood Diversification and Natural Resource Access. FAO, WP No.9. Rome: Access to Natural Resources Sub-Program, Livelihood Diversification and Enterprise Development Sub-Program, Overseas Development Group, University of Anglia

Ellis, F. (2000). Rural Livelihoods and Diversity in Developing Countries. Oxford: Oxford University Press.

Feder, G, Onchan, T \& Chalamwong, Y. (1988). Land policies and farm performance in Thailand's forest reserve areas. Economic Development and Cultural Change 36(3):483-501.

Fernandes, L \& Woodhouse, PJ.(2008). Family farm sustainability in southern Brazil: an application of agrienvironmental indicators. Ecological Economics 66(2-3):243-257.

Fitzpatrick, D. (2006). Evolution and Chaos in Property Rights Systems: The Third World Tragedy of Contested Access. The Yale Law Journal 115(5):996-1048.

Gebremedhin, B \& Swinton, S. (2003). Investment in soil conservation in northern Ethiopia: the role of land tenure security and public programs. Agricultural Economics 29(1):69-84.

Heltberg, R. (2002). Property rights and natural resource management in developing countries. Journal of Economic Surveys 16(2):189-214.

Kabubo-Mariara, J. (2007). Land conservation and tenure security in Kenya: Boserup's hypothesis revisited. Ecological Economics 64:25-35.

Leeuwis, C \& van den Ban, A. (2004). Communication for Rural Innovation: Rethinking agricultural extension. Third Edition. India: Blackwell publishing.

Marenya, PP \& Barrett, CB. (2007). Household level determinants of adoption of improved natural resource management practices among smallholder farmers in western Kenya. Food Policy 32:515-536.

Mekonnen, A. (2009). Tenure security, resource endowments, and tree growing evidence from the Amhara region of Ethiopia. Land Economics 85(2):292-307.

Messer, N \& Townsley, P. (2003). Local Institutions and Livelihoods: Guidelines for Analysis. [O]. Available from :< http://www.livelihoods.org/info/guidance_sheets_pdfs/cover.pdf> [ Accessed on 25 January 2007].

North, DC. (1991). Institutions. Journal of Economics Perspectives 5(1):97-112.

Pasteur, K. (2001). Tools for Sustainable Livelihoods: Policy Analysis. Brighton: Institute of Development Studies.

Pender, J \& Gebremedhin, B. (2007). Determinants of agricultural and land management practices and impacts on crop production and household income in the highlands of Tigray, Ethiopia. Journal of African Economies 17(3):395-450.

Pender, JL \& Kerr, JM. (1998). Determinants of farmers' indigenous soil and water conservation investments in semiarid India. Agricultural Economics 19(1-2):113-125.

Perrt, SR \& Stevens, JB. (2006). Socio-economic reasons for low adoption of water conservation technologies by smallholder farmers in Southern Africa: a review of the literature. Development Southern Africa 23(4):461- 476.

Place, F. (2009). Land tenure and agricultural productivity in Africa: a comparative analysis of the economics literature and recent policy strategy and reforms. World Development 37(8):1326-1336.

Platteau, JP. (1996). The evolutionary theory of land rights as applied to sub-Saharan Africa: a critical assessment. Development and Change 27(1):29-86.

Platteau, JP. (2000). Land tenure, economic growth and poverty in sub-Saharan Africa, in Evolving land rights, policy and tenure in Africa, edited by C Toulmin \& J Quan. London: Department for International Development, International Institute for Environment and development and Natural Resources Institute.

Reardon, T \& Vosti, SA. (1995). Links between rural poverty and the environment in developing countries: asset categories and investment poverty. World development 23(9): 1495-1506.

Scherr, SJ. (2000). A downward Spiral? Research Evidence on the relationship between poverty and natural resource degradation. Food Policy 25(4):479-498.

Scoones, I. (1998). Sustainable Rural Livelihoods: A Framework for Analysis, IDS Working Paper no. 72.

Shankland, A. 2000. Analysing Policy for Sustainable Livelihoods, IDS Research Report 49. Brighton: IDS.

Shiferaw, B \& Holden, S.(1998). Resource degradation and adoption of land conservation technologies in the Ethiopian Highlands: A case study in Andit Tid, North Shewa. Agricultural Economics 18:233-247.

Shiferaw, B \& Holden, S. (1999). Soil erosion and smallholders' conservation decisions in the highlands of Ethiopia. World Development 27(4):739-752.

Smith, RE. (2004). Land tenure, fixed investment, and farm productivity: evidence from Zambia's southern province. World Development 32(10):1641-1661.

Swift, J \& Hamilton, K. (2001). Household Food and Livelihood Security, in Food Security in Sub-Saharan Africa, edited by S Devereux \& S Maxwell. London: ITDG publishing.

Thomson, AM. (2000). Sustainable Livelihoods Approaches at the Policy Level. Paper prepared for FAO e-conference and forum on operationalizing participatory ways of applying sustainable livelihoods approaches. Rome: FAO.

Van de Flier, E \& Braun, AR. (2002). Conceptualizing integrative, farmer participatory research for sustainable agriculture: From opportunities to impact. Agriculture and Human Values 19:25-38. 
Vilei, S. (2011). Local perceptions of sustainability of farming systems on Leyte, Philippines: divergences and congruencies between different stakeholders. International Journal of Sustainable Development and World Ecology first edited (i first):1-13.

Wannasai, N \& Shrestha, RP. (2007). Determinants of rural land-use change in Prasae watershed area of Thailand. Asia-Pacific Journal of Rural Development 18(2):47-60. 